Technical Paper

\title{
Comprehensive Evaluation Method for Rice Husk Combustion to Establish Biomass Recycling System
}

\author{
Yuji Kubota ${ }^{* 1}$, Ryozo Noguchi ${ }^{* 2}$, Yasuyuki HidAKA *3, Takahiro NodA *3, \\ Takuma GENKAWA ${ }^{* 2}$, Tofael AHAMED ${ }^{* 2}$, Tomohiro TAKIGAWA $* 2$ \\ (Received February 18, 2014)
}

\begin{abstract}
This study proposed a comprehensive evaluation method for rice husk combustion in rural areas. The evaluation was considered with the aspects of economic value of energy as conventional evaluation criterion, environmental impact, and economic value of rice husk charcoal in the recycling system. Inventory analysis was conducted to estimate material and energy flow for inputs and outputs of a rice husk burner (Kaneko Agricultural Machinery Co. Ltd. Saitama, Japan). Inventory data was collected for the combustion experiment using the rice husk burner. Results revealed that $14.4 \mathrm{~kg}$-fuel/h of rice husk supply was the highest value of overall evaluation, because of producing valuable rice husk charcoal as by-product and small quantity of harmful substances in rice husk combustion. Trade-off relationship between economic value of energy, environmental impact, and the economic value of rice husk charcoal was observed in variations of the integrated result. It was clarified that the comprehensive evaluation method contributed to achieve high economic value of energy, low environmental impact, and high economic value of RHC simultaneously.
\end{abstract}

本研究では, 農村地域における籾殼燃焼の総合的評価手法を提案した。評価は, 従来からの評価項目としてのエネルギーの経 済価值, 環境影響, 循環型システムに抂ける籾殼燻炭の経済価值の観点が考慮された。インベントリ分析によって, 籾殼燃焼炉 (金 子農機株式会社）の入出力に関する物質エネルギーフローが推定された。インベントリデー夕は, 籾殼燃焼炉を用いた籾殼燃焼実 験において収集された。籾殼供給量が $14.4 \mathrm{~kg} / \mathrm{h}$ の条件下において, 籾殼燃焼での有用な副産物としての籾殼燻炭の生産と, 少 ない環境負荷により, 最も評価值が高くなることが明らかとなった。統合された結果の変化から, 総合評価の結果より, エネルギー の経済価值, 環境影響, および籾殼燻炭の経済価值の間で, トレードオフの関係が示された。籾殼燃焼に対する総合評価は, 高 いエネルギー経済価值, 低い環境影響, および籾殼櫄炭の高い経済経済を同時に達成することに, 貢献できることが明らかとなった。

\section{Key Words}

Rice husk, Life Cycle Assessment, Incineration, LIME2, Environmental impact

\section{Introduction}

About 1.8 million t/year of rice husk is produced in Japan ${ }^{1)}$. Rice husk is separated after drying and husking of rice production process as a by-product. Rice husk is expected as alternative energy resources for grain drying and green house heating in the agricultural sectors, because

※1 Graduate School of Life and Environmental Sciences, University of Tsukuba

1-1-1, Tennodai, Tsukuba-shi, Ibaraki 305-8577, Japan

※2 Faculty of Life and Environmental Sciences, University of Tsukuba

1-1-1, Tennodai, Tsukuba-shi, Ibaraki 305-8577, Japan

※3 National Agriculture and Food Research Organization 3-1-1, Kannoudai, Tsukuba-shi, Ibaraki 305-8517, Japan about $40 \%$ of produced rice husk is unused ${ }^{2)}$, and moisture content of rice husk is very low after the drying process of rice. In addition, rice husk is expected for not only as energy resource but also production of Rice Husk Charcoal (RHC) for soil amendments ${ }^{3)}$. Effective rice husk combustion system promotes the formation of energy recycling system in rural areas.

The rice husk burner was discussed in this research and development (R\&D) as a background of two oil crises in 1970s. Recently, remarkable rising of oil price from 2004 to 2008 and global warming issues progressed the technology of the rice husk burner again ${ }^{4)}{ }^{5}$. Academic reports of International Agency for Research on Cancer suggested 


\section{Conventional method}

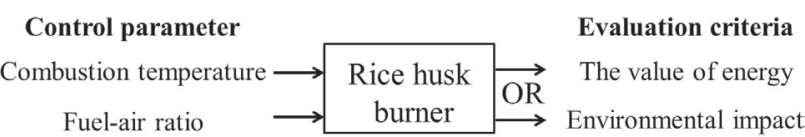

\section{Comprehensive evaluation method}

\begin{tabular}{|c|c|c|}
\hline Control parameter & & Evaluation criteria \\
\hline & & The value of energy \\
\hline Fuel-air ratio & $\begin{array}{c}\text { Rice husk } \\
\text { burner }\end{array}$ & $\underset{\text { AND }}{\longrightarrow}$ Environm \\
\hline
\end{tabular}

Fig. 1 Conceptual diagram of conventional and comprehensive evaluation methods

that rice husk combustion at high temperature causes silicon (Si) in the husk to form carcinogenic crystalline cristobalite and tridymite ${ }^{6}$. Therefore, amount of crystalline $\mathrm{Si}$ in air should be regulated for occupational health ${ }^{7}$. RHC is produced as effective soil amendments by rice husk combustion, when the combustion temperature is below $800{ }^{\circ} \mathrm{C}^{8}$. Therefore, the recent trend of $\mathrm{R} \& \mathrm{D}$ for rice husk combustion has to avoid for perfect combustion to improve the energy efficiency, that was mentioned in the 1970s.

Energy efficiency, amount of emitted hazardous substances, and effectiveness for soil amendment using RHC are influenced by the temperature and fuel-air ratio of rice husk combustion. The past research dealt with the values of energy, "or" environmental impact of hazardous substances separately ${ }^{9}{ }^{10}$. However, the value of energy "and" environmental impact of hazardous substances should be considered as essential factors simultaneously to evaluate rice husk combustion comprehensively. On the other hand, it is necessary to maximize benefit obtained from the rice husk burner operation in these days. Furthermore, the economic value of RHC is also important for diffusion of the rice husk burner in rural areas.

Therefore, the objective of this research is to establish a comprehensive evaluation method considering three aspects of rice husk: economic value of energy, environmental impact, economic value of RHC. Conventional and comprehensive evaluation methods were also compared based on selected criteria (Fig. 1). Furthermore, the research was designed to introduce the sustainable biomass recycling system in rural areas by controlling of rice husk combustion, effectively.

\section{Materials and Methods}

Material and energy flow for inputs and outputs of rice husk burner was estimated using the inventory analysis of Life Cycle Assesment (LCA). Inventory data was obtained by combustion experiments at the National Agriculture and Food Research Organization, Saitama-

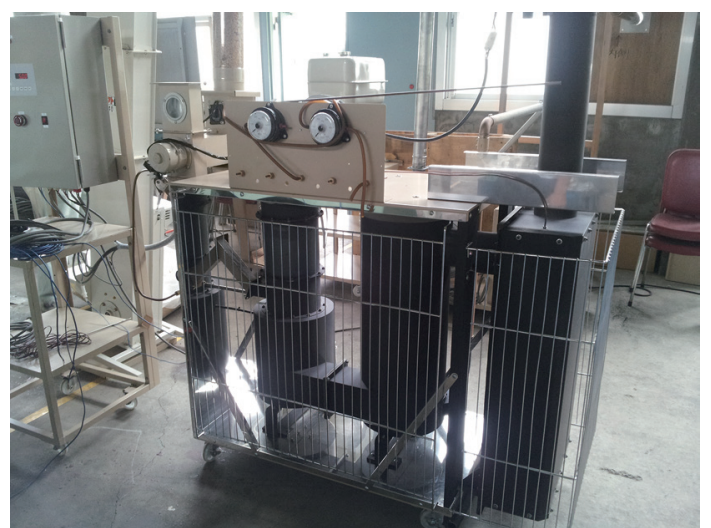

Fig. 2 Swirling combustion equipment: Air-K (Kaneko Agricultural Machinery Co. Ltd, Saitama)

city, Japan. Amount of rice husk supply was a controllable parameter in the experiment.

Usually, larger amount of rice husk supply produced higher temarature in the furnace. With this consideration, the range of rice husk supply was set from 13.1 to 20.3 $\mathrm{kg}$-fuel/h for the combustion experiment to keep safe condition of furnace. It is required to keep the combustion temperature $450{ }^{\circ} \mathrm{C}$ for burning rice husk stable ${ }^{9}$. The furnace of the rice husk burner is melted at temperatures higher than $1000^{\circ} \mathrm{C}^{11}$.

Swirling combustion equipment Air-K (Kaneko Agricultural Machinery Co. Ltd, Saitama) was used for the experiment of rice husk combustion (Fig. 2). Combustion temperature, flue gas temperature, and concentration of exhaust gas $\left(\mathrm{CO}, \mathrm{CO}_{2}, \mathrm{NO}_{\mathrm{x}}, \mathrm{SO}_{2}, \mathrm{O}_{2}\right)$ were measured by a flue gas analyzer (Testo350, Testo Co. Ltd). The weight of RHC were also measured.

The economic value of energy, environmental impact, and the economic value of RHC were calculated based on the material and energy flow and their analysis data of rice husk combustion in the experiment. The economic value of energy was calculated from lower heating value of rice husk and RHC, heating value of kerosene, and the market price of kerosene. The economic value can be expressed as:

$$
V_{E}=\frac{E_{R H}-E_{R H C}}{H_{k e}} \times P_{k e}
$$

where $V_{E}$ is the economic value of energy [JPY/h], $E_{R H}$ is the lower heating value of rice husk supply per hour $[\mathrm{MJ} / \mathrm{h}], E_{R H C}$ is the lower heating value of $R H C$ produced per hour $[\mathrm{MJ} / \mathrm{h}], H_{k e}$ is the lower heating value of kerosene and the market price of kerosene $P_{k e}$ (106.6 JPY/L, June 9, 2014).

Environmental impact due to rice husk combustion per unit time was evaluated as damage cost by using LIME2 (Life-cycle Impact assessment Method based on 
Endpoint modeling) ${ }^{11}$. The environmental impact was calculated from impact substance, influence territory and life cycle inventory data. The damage cost can be expressed as:

$$
S I=\sum_{\text {Impact }} \sum_{X} I F^{I m p a c t}(X) \cdot \operatorname{Inv}(X)
$$

$S I$ is the damage cost by environmental impact, [JPY/ h], $X$ is the environmental impact substance, Impact is the influence territory, $I F^{\text {Impact }}(X)$ is an integration coefficient of $X[\mathrm{JPY} / \mathrm{kg}$ ], and $\operatorname{Inv}(X)$ is the life cycle inventory data per unit time of $X[\mathrm{~kg} / \mathrm{h}]^{12)}$.

The economic value of $R H C$ was evaluated based on the value of soil amendments. The saturated solubility in water of silicates in $R H C$ affects effectiveness of soil amendments ${ }^{8)}$. The solubility of silicates in raw rice husk was low, because coexisting lignocellulose inhibited elution of silicates. Lignocellulose stored in rice husk was removed by rice husk combustion. However, silicates were crystallized at the same time with reducing the solubility. The solubility of silicates of $R H C$ was maximized at low-temperature rice husk combustion (about $400{ }^{\circ} \mathrm{C}$ ), where lignocellulose was combusted and degree of silicates crystallization was low. The value of $R H C$ was estimated from the amount of produced $R H C$, the solubility of silicates and the market price of $R H C$. The value can be expressed as:

$$
V_{R H C}=M_{R H C} \frac{S_{C}}{S_{M}} \times P_{R H C}
$$

$V_{R H C}$ is the value of $R_{H C}[\mathrm{JPY} / \mathrm{h}], M_{R H C}$ is the amount of produced $R H C[\mathrm{~kg} / \mathrm{h}], R H C S_{C}[\%]$ is the solubility of silicates, $S M$ is the solubility of silicates in $R H C$ available on the market [\%], and $P_{R H C}$ is the market price of $R H C$ [JPY $/ \mathrm{kg}$ ]. $S_{C} / S_{M}$ is the ratio of produced $R H C$ as a fertilizer compared to those on the market. The economic value of energy, environmental impact, and the economic value of $R H C$ are combined and expressed as the integrated result of $I R_{\text {com }}$.

$$
I R_{\text {com }}=V_{E}-S I+V_{R H C}
$$

Table 1 Impact substances produced by rice husk combustion

\begin{tabular}{ccc}
\hline$X$ & Impact & $\begin{array}{c}I F^{\text {Impact }}(X) \\
{[\mathrm{JPY} / \mathrm{kg}]}\end{array}$ \\
\hline $\mathrm{CO}_{2}$ & Global warming & 2.33 \\
\hline $\mathrm{NO}$ & Acidification & $1.48 \times 10^{2}$ \\
\hline $\mathrm{NO}_{2}$ & Acidification & $9.57 \times 10^{1}$ \\
\hline $\mathrm{SO}_{2}$ & Acidification & $1.20 \times 10^{2}$ \\
\hline $\mathrm{NO}_{2}$ & Air pollution & $1.72 \times 10^{2}$ \\
$\mathrm{SO}_{2}$ & Air pollution & $2.11 \times 10^{3}$ \\
\hline
\end{tabular}

$X$ : environmental impact substance

Impact : influence territory

$I F^{\text {Impact }}(X)$ : integration coefficient of $X$
Higher value of $I R_{\text {com }}$ shows superior evaluation of rice husk combustion.

\section{Results and Discussion}

Measurement results of combustion temperature, exhaust gas temperature, and concentration of exhaust gas are shown in Fig. 3 and listed in Table. 2. Material and energy flow of rice husk burner is shown in Fig. 4.

Due to constant air inflow $\left(76.8 \mathrm{~m}^{3} \mathrm{~N} / \mathrm{h}\right)$ maintained during combustion, the fuel-air ratio was decreased by

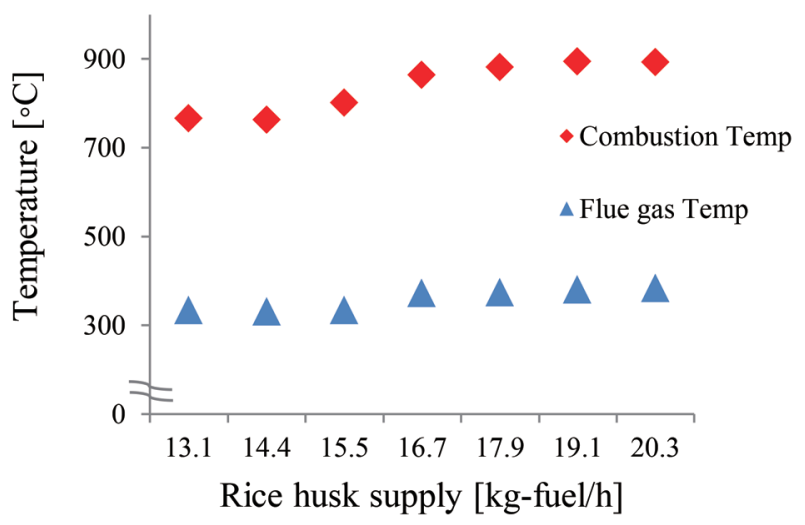

Fig. 3 Temperature distribution at the different of levels of rice husk supply

Table 2 Exhaust gas components and their concentration during rice husk combustion

\begin{tabular}{c|cccccc}
\hline $\begin{array}{c}\text { Rice husk } \\
\text { supply } \\
\mathrm{kg}-f u e l / h\end{array}$ & $\mathrm{CO}$ & $\mathrm{CO}_{2}$ & $\mathrm{NO}$ & $\mathrm{NO}_{2}$ & $\mathrm{SO}_{2}$ & $\mathrm{O}_{2}$ \\
\hline 13.1 & 1152 & 11.1 & 336 & 5.3 & 0.0 & 8.3 \\
14.4 & 1182 & 11.2 & 341 & 3.6 & 0.0 & 8.3 \\
15.5 & 823 & 12.0 & 361 & 4.4 & 0.0 & 7.6 \\
16.7 & 629 & 14.7 & 293 & 0.0 & 0.1 & 4.8 \\
17.9 & 586 & 15.2 & 295 & 0.0 & 3.6 & 4.3 \\
19.1 & 546 & 15.8 & 290 & 0.0 & 4.2 & 3.7 \\
20.3 & 461 & 16.2 & 329 & 0.0 & 16.2 & 3.4 \\
kerosene & 51 & 7.1 & 42.9 & 1.1 & 0.0 & 10.2 \\
\hline
\end{tabular}
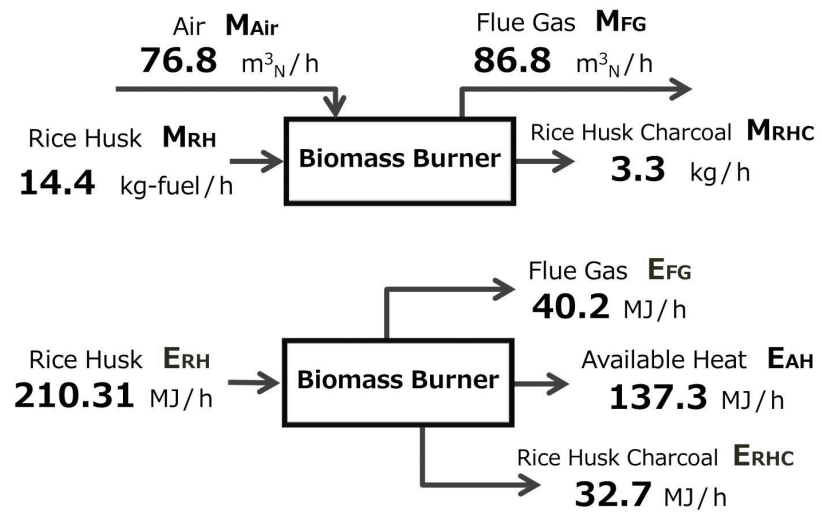

Fig. 4 Material and Energy flow of the rice husk combustion: Rice husk supply: 14.4 kg-fuel/h 
increasing of rice husk supply (Fig. 5). The energy was increased with increasing of rice husk supply. Burnt carbon index from rice husk was approximated and perfect combustion was found while combustion temperature was increased under enough air inflow (Fig. 6). Hence, the energy efficiency became higher and approached a certain value while the rice husk supply was increased (Fig. 7).

The economic value of energy is shown in Fig. 8. With increasing in rice husk supply, the economic value of

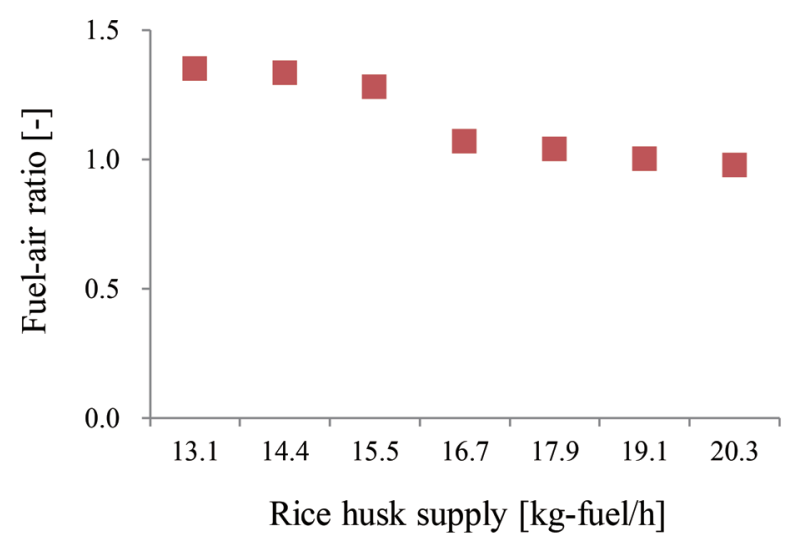

Fig. 5 Relationship between fuel-air-ratio and rice husk supply

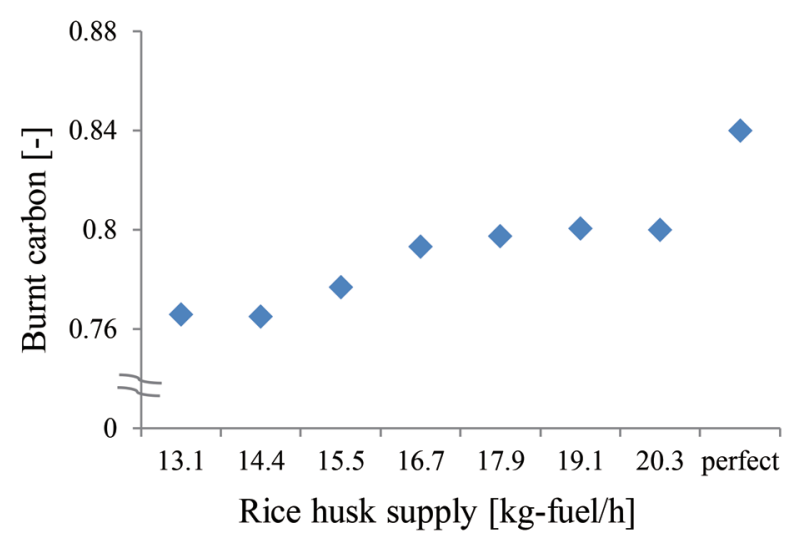

Fig. 6 Relationship between the amount of burnt carbon index from rice husk and rice husk supply

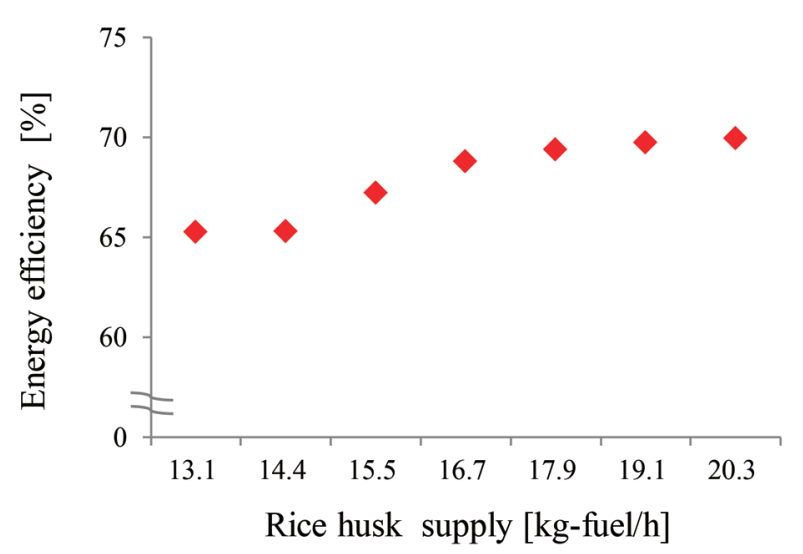

Fig. 7 Variations of energy efficiency at the different levels of rice husk supply energy was increased.

Environmental impact assessment by LIME2 is shown in Fig. 9. $\mathrm{CO}_{2}$, that was produced from rice husk combustion was the most influential gas of global warming, and air pollution due to $\mathrm{SO}_{2}$ was the second influential components. $\mathrm{SO}_{2}$ produced from combustion was increased due to higher amount of rice husk supply while fuel-air ratio was lower. Hence, high environmental impact was found, while $20.3 \mathrm{~kg}$-fuel/h of rice husk was supplied in combustion experiment.

The economic value of RHC is shown in Fig. 10. When the total amount of rice husk supply was increased, the crystallization of silicates in RHC was advanced. Then, the value of RHC was decreased by crystallization of silicates. $14.4 \mathrm{~kg}$-fuel/h of rice husk supply indicated the highest value of economical efficiency in the experiment.

Trade-off relationship between the economic value of energy and the economic value of RHC was observed in variations of the integrated result noted as $I R_{\text {com }}$ (Fig. 11). In this $I R_{\text {com }}, 14.4 \mathrm{~kg}$-fuel/h of rice husk supply indicated the highest value by large economic value of RHC (Fig. 11).

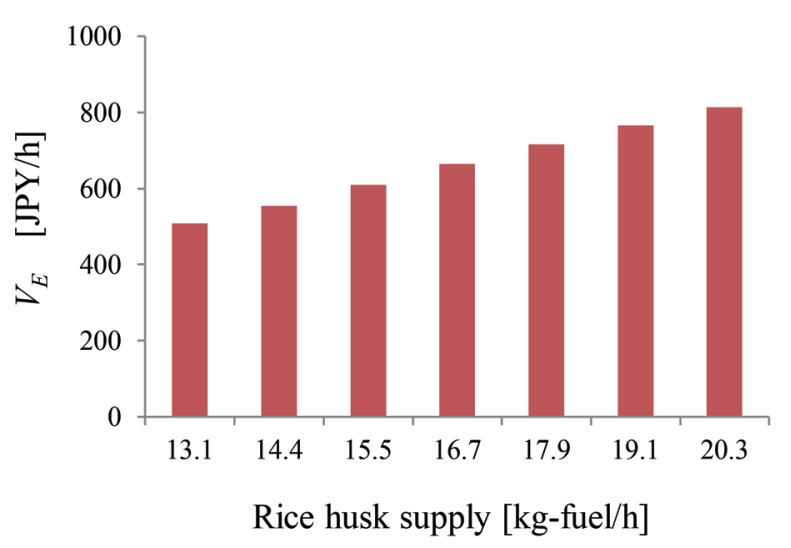

Fig. 8 Variations of the economical value of energy caused by rice husk supply

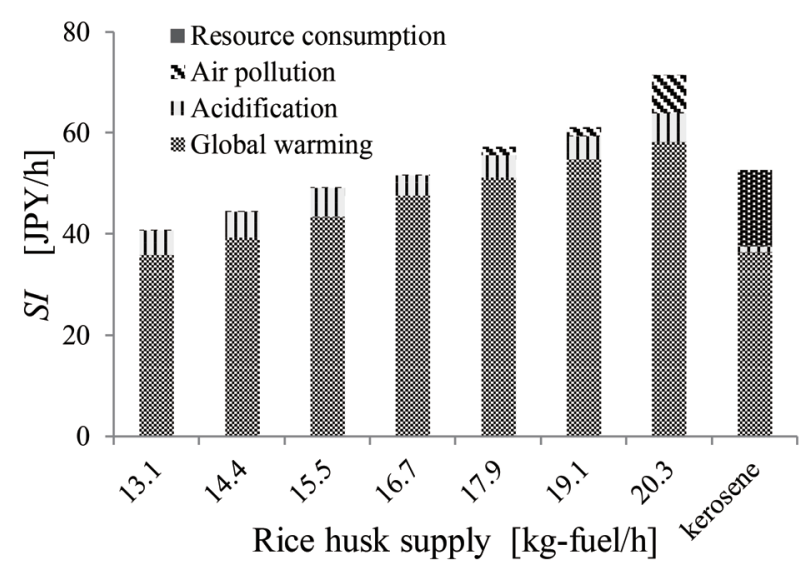

Fig. 9 Environmental impact due to rice husk combustion by LIME2 


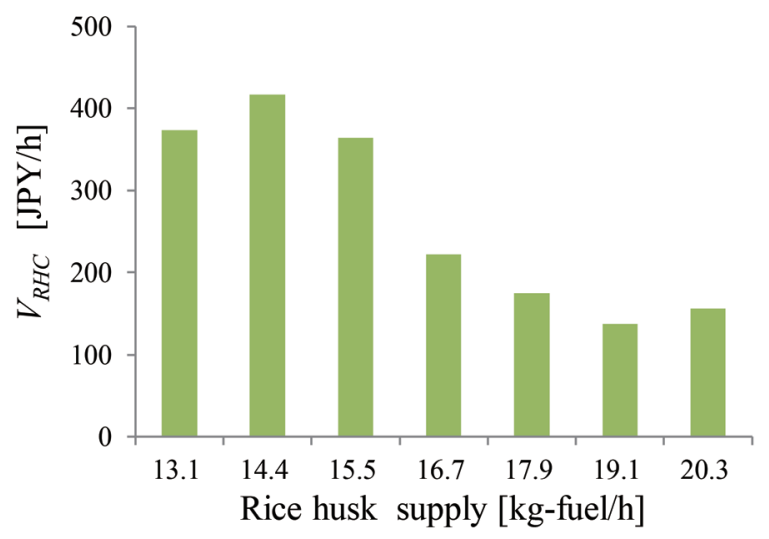

Fig. 10 Variations of the economic value of $\mathrm{RHC}$ caused by rice husk supply

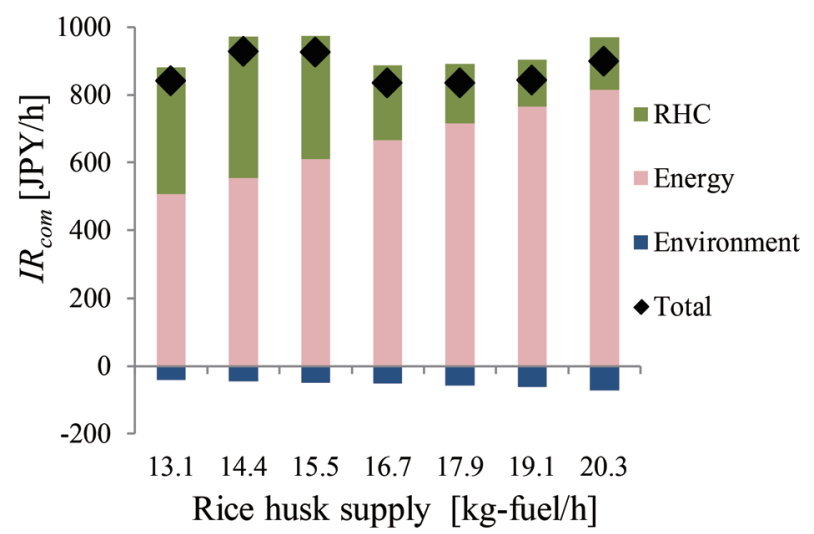

Fig. 11 Variations of the integrated result caused by rice husk supply

However, in the conventional evaluation method, $I R_{\text {com }}$ of 14.4 $\mathrm{kg}$-fuel/h of rice husk supply could not reach the highest value compared with other levels of rice husk supply.

The comprehensive evaluation method showed versatile result compared with a conventional evaluation method. Thus, it was clarified that the comprehensive evaluation method contributed to achieve high economic value of energy, low environmental impact, and high economic value of RHC, simultaneously. This evaluation method showed that the rice husk burner can be introduced to the rural areas and the rice husk combustion can be controlled effectively according to the purpose of operator, agricultural production, and environment.

\section{Conclusions}

The comprehensive evaluation method considering economic value of energy, environmental impact, and economic value of RHC was proposed. The experiments were conducted to investigate the properties using rice husk combustion experiment. The following conclusions can be drawn:

1) $\mathrm{CO}_{2}$ was the most influential gas followed by $\mathrm{SO}_{2}$ for global warming and air pollution on environmental impact in the rice husk combustion.

2) When the total amount of rice husk supply was increased, the crystallization of silicates in RHC was advanced. Then, the value of RHC was decreased by crystallization of silicates.

3) Trade-off relationship between economic value of energy and the economic value of RHC was observed in variations of the integrated result of IRcom. In the IRcom experiment, we found that $14.4 \mathrm{~kg}$-fuel $/ \mathrm{h}$ of rice husk supply was the highest value to ensure the large economic value of RHC.

4) The comprehensive evaluation method contributed to achieve high economic value of energy, low environmental impact, and high economic value of RHC simultaneously.

\section{References}

1) Ministry of Agriculture, Forestry and Fisheries, Crops statistics, Crops investigation, rice plant 2013, http:// www.maff.go.jp/j/tokei/kouhyou/sakumotu/sakkyou_ kome/index.html\#r (Last access: 2013. 5. 13)

2) NEDO, Estimate of the available quantity of rice husk, 2005, http://www.oo.em-net.ne.jp/〜y-ogisu/momigara. pdf. (Last access: 2012. 8. 27)

3) Moriizumi, M.; Prakash, N. B.; Ito, S., J. Japanese Journal of Soil Science and Plant Nutrition, 75(5), 609-612 (2004) (in Japanese)

4) Using rice husk in drying of grains, reference material from the 8th Postharvest Machinery Section Meeting of The Japanese Society of Agricultural Machinery and Food Engineers. 1981 (in Japanese)

5) Use of rice husk in grain drying and processing facilities, Grain Drying and Storage Facility Association, 2009 (in Japanese)

6) IARC, Silica and some silicates. Lyon, France, International Agency for Research on Cancer, pp. 33143 (1987)

7) Shinohara, Y.; Kohyama, N., Industrial Health, 42, 277285 (2004)

8) Ito, S., J. Japan Association for Techno-innovation in Agriculture, Forestry and Fisheries, 29(4), 13-17 (2006)

9) Wang, O.; Maezono, T.; Domon, M. et al., J. The Japan Institute of Energy, 47, 22-23 (2010) (in Japanese)

10) Feng, D.; Chiensong, C.; Yucheng, C.; Jim, T., J. Journal of Environmental Sciences, 25(2), 335-339 (2013)

11) Hujiwara, I.; Domon, M.; Morita, K. et al., Report of Comprehensive Open Innovation Center, (9), 77-84 (2010) (in Japanese)

12) Itsubo, N.; Inaba, A., LIME2 - Environmental impact assessment method to support decision making -, Japan 
Environmental Management Association for Industry, pp. 578-605 (2010) (in Japanese)

13) Thipwimon, C.; Shabbir H, G.; Suthum, P., J. Proceedings of World Academy of Science: Engineering \& Technolog, 53, 1064-1069 (2009)

14) Hasegawa, I., in Biomass Process Handbook, Society of
Chemical Engineers Japan, Japan Institute of Energy, Eds., Ohm-sha, (2012) (in Japanese)

15) Mizutani, Y., Introduction to combustion engineering for environmental conservation and energy saving, Morishita Publishing, (2003) (in Japanese) 